
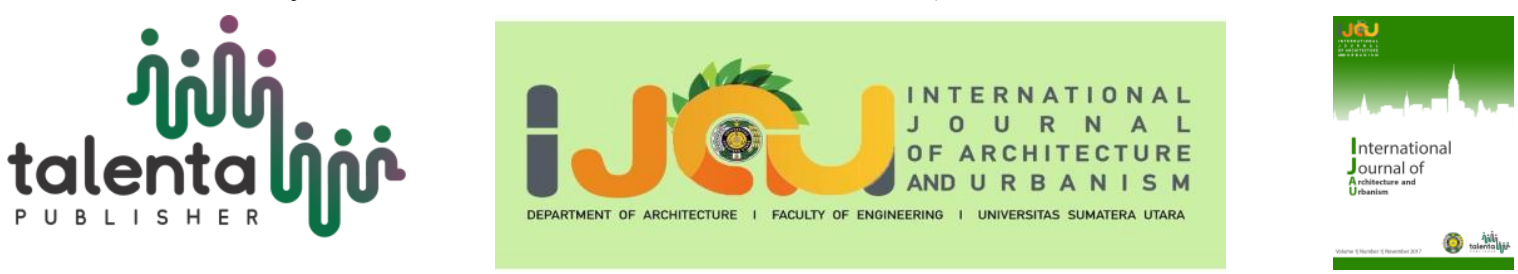

\title{
Research on determining the aseismic performance level of reinforced concrete building
}

\author{
Jong-Bom $\operatorname{Han}^{1 *}$ \\ ${ }^{1}$ Pyongyang University of Architecture, DPRK
}

\begin{abstract}
In seismic design based on performance, seismic performance level is determined based on failure state of the building and seismic design objective is set according to the importance of the buildings. In many countries, they calculate the seismic reaction of the buildings with the use of structural design programs to check the aseismic performance through the nonlinear static analysis method. In this paper, we established seismic performance levels and aseismic design objective to design on the basis of design objective according to the three levels in Seismic Design Code of Building, DPR Korea, 2010.
\end{abstract}

Keyword: failure, performance, seismic, aseismic, design

Received 15 July 2021|Revised 22 August 2021 | Accepted 26 August 2021

\section{Introduction}

Since the idea about seismic design based on performance was suggested, many researches and experiments have been taken place. FEMA 273/274 [3,4] suggested seismic design objective relying on performance level of structural and non-structural members and the main methods of deciding seismic performance of buildings with the use of nonlinear static analysis(Pushover) to evaluate the seismic performance.

ATC40 [2] reported the main principle of capacity spectrum method and the method to evaluate the seismic performance and described the evaluation method according to usage and failure state. With the development of seismic design theories, we can design on the economic standard considering the importance of the buildings and evaluate aseismic performance of buildings under various earthquake technically.

\footnotetext{
*Corresponding author at: Taedonggang Dong, Taedonggang District, Pyongyang, DPRK

E-mail address: shypinguo202121@yeah.net
}

Copyright (C) 2021 Published by Talenta Publisher, 


\section{Seismic Design Code of Building, DPR Korea}

1) Design objectives according to the three levels in Seismic Design Code of Building is shown in table 1 and these objectives can be realized through the design of second stage.

Table 1 The three levels and design objective

\begin{tabular}{lcl}
\hline \multicolumn{1}{c}{ Design level } & $\begin{array}{c}\text { Exceeded } \\
\text { Probability } \\
\text { during design } \\
\text { period }\end{array}$ & \multicolumn{1}{c}{ Design objective, behavior, reparability } \\
\hline $\begin{array}{l}\text { Stage } 1 \\
\text { (Slight seismic) }\end{array}$ & $63.2 \%$ & $\begin{array}{l}\text { Design for full repair from seismic failure } \\
\text { In elastic behaviour }\end{array}$ \\
$\begin{array}{l}\text { Stage } 2 \\
\text { (normal seismic) }\end{array}$ & $10 \%$ & $\begin{array}{l}\text { Some part is in elastic behaviour, } \\
\text { Design for slight faliure in structural members } \\
\text { Stage 3 }\end{array}$ \\
(strong seismic) & $2 \sim 3 \%$ & $\begin{array}{l}\text { Most of the building is in elastoplastic behaviour, } \\
\text { the building is not destructed though in elastoplastic } \\
\text { concentration behavior. } \\
\text { However it is difficult to repair. }\end{array}$ \\
& &
\end{tabular}

Stage 1-bearing capacity, checking deformation and seismic measure of the structure and structural members under small seismism. Stage 2-collapse prevention by elastoplastic deformation check under action of strong earthquake. Relation between slight earthquake, normal earthquake and strong earthquake is shown in figure 1.

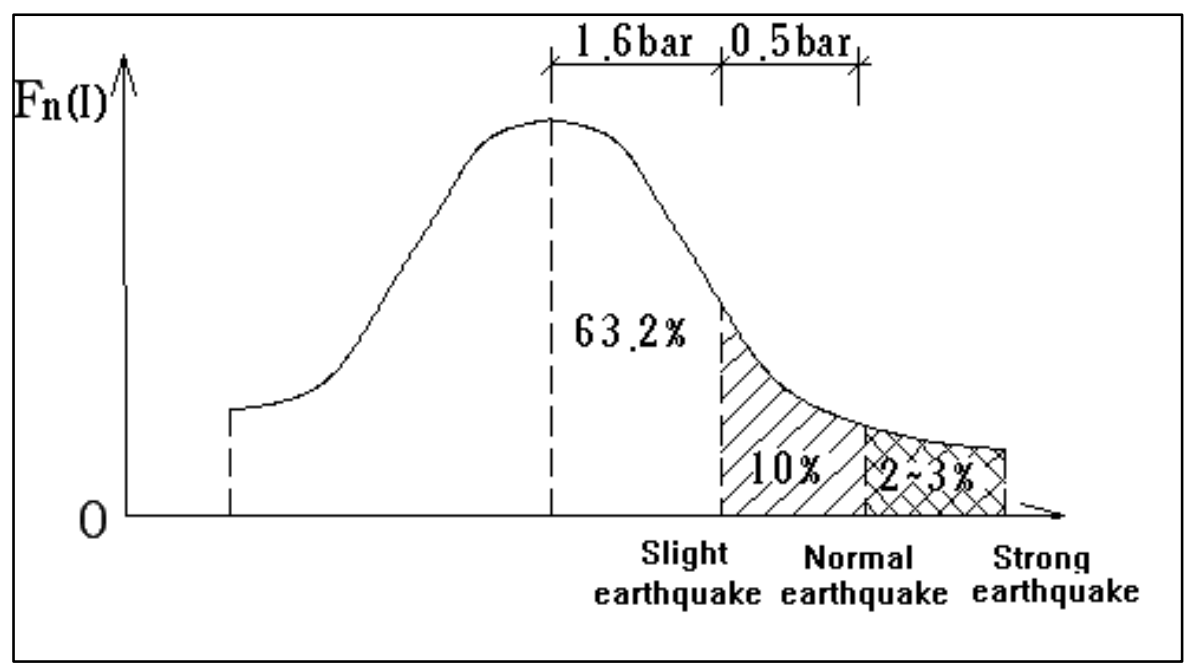

Figure 1 Probability distribution of seismic strength

2) Table 2 shows the classification according to the importance of the buildings and the design seismic strength of the buildings according to the local seismic strength. 
Table 2 classification according to the importance of the buildings and design seismic strength, bar

\begin{tabular}{|c|c|c|c|c|}
\hline \multirow{3}{*}{ Characteristics of buildings } & \multirow{2}{*}{\multicolumn{2}{|c|}{$\begin{array}{c}\text { Seismic design } \\
\text { local seismic } \\
\text { strength,bar }\end{array}$}} & \multicolumn{2}{|c|}{ Seismic measure } \\
\hline & & & \multicolumn{2}{|c|}{ local seismic strength, bar } \\
\hline & 6 & 7 & 6 & 7 \\
\hline $\begin{array}{l}\text { Important buildings and the } \\
\text { Class } 1 \text { buildings that can occur serious } \\
\text { secondary damage } \\
\text { earthquake }\end{array}$ & 7 & $\begin{array}{l}\text { Determine } 7 \\
\text { or } 8 \text { bar after } \\
\text { consultation }\end{array}$ & 7 & $\begin{array}{l}8 \\
\text { (7 at ground } \\
\text { of class } 1)\end{array}$ \\
\hline $\begin{array}{l}\text { Buildings which should not stop to } \\
\text { use even under } \\
\text { earthquake(buildings of electricity } \\
\text { Class } 2 \text { supply, buildings related to water } \\
\text { supply and drainage, hospital, fire- } \\
\text { fighting center), or buildings to be } \\
\text { repaired instantly }\end{array}$ & - & 7 & $\begin{array}{l}7 \\
\text { (6 at gro } \\
\text { class1) }\end{array}$ & $\begin{array}{c}8 \\
\mathrm{f}(7 \text { at ground } \\
\text { of class } 1)\end{array}$ \\
\hline $\begin{array}{l}\text { Class } 3 \text { The rest of buildings of class } 1,2 \\
\text { and } 4\end{array}$ & - & 7 & 6 & $\begin{array}{c}7 \\
\text { (6 at ground } \\
\text { of class } 1)\end{array}$ \\
\hline $\begin{array}{l}\text { Secondary buildings which is little } \\
\text { Class } 4 \text { damaged,buildings to two stories } \\
\text { and public and industrial building } \\
\text { with the height of two stories }\end{array}$ & - & - & - & $\begin{array}{c}7 \\
\text { (not consider) }\end{array}$ \\
\hline
\end{tabular}

Note: buildings of class 4 can be applied by seismic measure lower than normal seismic one and buildins of class 2 can be reinforced concrete buildings or steel structure of good seismic performance which can be applied by proper seismic measureof the rules according to the local seismic strength.

\section{Decision of seismic performance according to Seismic Design Code of Building of our country}

Generally, seismic performance can be classified by destructive state of the structures. Failure state can be divided into 5 levels (non-destructive state, slight destructive state, medium destructive state, serious destructive state, collapse) on basis of earlier studies and experimental data to decide the seismic performance level of the structures based on it.

\section{1) Destructive state of the structures}

(1) Non-destructive state

Most structural members are in elastic behavior in this state, so it is called "regular operation". About 5 percent of structural members has ductile behavior with slight cracks and the rest of them works in elastic behavior. 
(2) Slight destructive state

In this state, some of the structural members has slight ductile deformation which can't reach yielding to be still in regular operation. Deformation of the structural member is 1.5 2 times as large as elastic deformation and little deformation such as crack occurs in main structural members and the rest members are damaged locally in different scale. About 30 percent of structural members are in destructive state with crack occurrence.

(3) Medium destructive state

In this state, deformation of the structural members are in medium stage of elastoplastic deformation and bearing capacity of the members are in critical state.

Structural members are clearly in ductile failure and they are reparable and the cost for repairing is smaller than the construction cost. Fifty percent of the whole structure are in medium stage failure and five percent of the members are in serious destructive state(ninety percent of elastic deformation limit).

(4) Serious destructive state

This state is one which deformation of the structural members reach to the ninety percent of the elastoplastic deformation limit. Fifty percent of the whole structure are in serious destructive state. This state makes repairing less possible and costs more than construction cost.

(5) collapse

In this state, most of the members reach elastoplastic deformation limit and the building collapse locally or completely. It is impossible to repair and it endangers lives.

\section{2) Decision of seismic performance level and design objectives}

Seismic performance levels of reinforced concrete buildings can be determined as follows on basis of failure state of the structure [1].

Table 3 Seismic performance levels of reinforced concrete buildings

\begin{tabular}{lccc}
\hline Performance level & safety & usability & Failure state \\
\hline Performance level 1 & safe & Instant use & Non-destructive \\
Performance level 2 & safe & Use after slight repair & Slight destructive \\
Performance level 3 & Life safe & Use after repair & Medium destructive \\
Performance level 4 & Life danger & Unable to repair & Serious destructive \\
\hline
\end{tabular}


Performance level 5 Life danger $\quad$ Unable to use collapse

Seismic Design Code of Building of our country classifies seismic strength into three levels: slight earthquake, normal earthquake, strong earthquake. In slight seismic strength, exceeded probability of design period is $63.2 \%$, normal seismic $10 \%$, strong seismic $2 \sim 3 \%$ and seismic acceleration is shown in table 2 .

Table 4 design seismic strength and design seismic acceleration

\begin{tabular}{ccc}
\hline design seismic strength, bar & 7 & 8 \\
\hline $\begin{array}{c}\text { Design value of normal } \\
\text { seismic acceleration } \\
\quad \begin{array}{l}\text { Design value of slight } \\
\text { seismic acceleration }\end{array}\end{array}$ & $0.10 \mathrm{~g}$ & $0.20 \mathrm{~g}$ \\
$\quad \begin{array}{l}\text { Design value of strong } \\
\text { seismic acceleration }\end{array}$ & $0.150 \mathrm{~g}$ & $0.064 \mathrm{~g}$ \\
\hline
\end{tabular}

Note: $g$ is acceleration of gravity.

Seismic design objectives of reinforced concrete buildings can be determined as follows on basis of seismic strengths and seismic performance levels.

Table 5 objectives of seismic design

\begin{tabular}{cccccc}
\hline Performance level & level1 & level2 & level3 & level4 & level5 \\
earthquake & & & & & \\
\hline Slight earthquake & 3 & 4 & 5 & - & - \\
Normal earthquake & $(2)$ & $(3$ & $(4)$ & 5 & - \\
Strong earthquake & 1 & $(2)$ & $(3$ & 4 & 5 \\
\hline
\end{tabular}

Seismic design objective (1) is one that the building is in performance level 1 under strong earthquake and can be used instantly, and can be applied to the very important buildings (Table 1). In our country, this objective is applied to the buildings of the first class in classification of buildings in our country.

Seismic design objective (2) is one that the building remains in performance level 1 under normal earthquake and has slight failures under strong earthquake, and can be applied to the buildings of the second class in classification of buildings in our country (Table 2). 
Seismic design objective (3) is one that the building remains in performance level 1 with nondestructive state under slight earthquake and is in medium stage of failure, and can be applied to the buildings of the third class in classification of buildings in our country (Table 3).

Seismic design objective (4) is one that slight failure occurs under slight earthquake and the building is in performance level 4 under normal earthquake, can be applied to the buildings of the fourth class in classification of buildings in our country (Table 4).

Seismic design objective (5) is one that requires life safety under normal earthquake and the building collapses under strong earthquake, and generally can be applied to the buildings which do not need to consider earthquake (Table 5).

As is shown, we can estimate the failure state of the buildings under earthquake to guarantee the building more scientifically when we classify the seismic performance levels of reinforced concrete building in to five and design according to it.

\section{Conclusion}

Calculation of story drift of the structure and decision of the structural performance levels is important for seismic design. In this essay, we decided the performance levels of the reinforced concrete structures and seismic design objective according to performance.

We laid the foundation of seismic design on the basis of performance by deciding performance levels of reinforced concrete structure considering the importance of the buildings.

\section{REFERENCES}

[1] Seismic Design Code of Building, DPRKorea, 2010

[2] ATC-40. Seismic evaluation and retrofit of concrete building, ATC, California, 1996.

[3] FEMA-273. NEHRP Guidelines for the Seismic Rehabilitation of Buildings, FEMA, Washington, D.C., 1997

[4] FEMA-274. NEHRP Commentary on the Guidelines for the Seismic Rehabilitation of Buildings, FEMA, Washington, D.C., 1997 